\title{
Science literacy skills through the experience of project activities with assisted local potential based learning materials
}

Diana Hernawati a,1,*, Mohamad Amin b,2, Mimien Henie Irawati Al Muhdhar b,3, Sri Endah Indriwati b,4

a Department of Biology Education, Faculty of Teacher Training and Education, Universitas Siliwangi Tasikmalaya, Siliwangi street No.24, Khuripan, Tawang, Tasikmalaya, West Java, 46115, Indonesia

${ }^{b}$ Department of Biology, Faculty of Mathematics and Natural Science, Universitas Negeri Malang, Semarang street No.5, Sumbersari, Lowokwaru, Malang, East Java, 65145, Indonesia

hernawatibiologi@unsil.ac.id*; ${ }^{2}$ mohamad.amin.fmipa@um.ac.id; ${ }^{3}$ mimien.henie.fmipa@um.ac.id; ${ }^{4}$ sri.endah.fmipa@um.ac.id

* corresponding author

$\begin{array}{ll}\text { ARTICLE INFO } & \text { ABSTRACT } \\ & \begin{array}{l}\text { Scientific skills literacy is one of the skills that students need to have to support the } \\ \text { learning process. This study aims to explain the literacy skills of the students through } \\ \text { project experience with the help of local potential-based teaching materials. This } \\ \text { Received January } 09,2019\end{array} \\ \text { research is a quantitative study and it used quasi-experimental design, pre-and posttest } \\ \text { Revised February 14,2019 } \\ \text { Accepted February 23, ANCOVA analysis was used as the data analysis technique at a significant level } \\ \text { Published March 12, 2019 } 5 \%(p<0.5) \text {. Analysis prerequisite tests included the Kolmogorov-Smirnov test for } \\ \text { normality test and homogeneity of variance with Levene's-Test. All data testing was } \\ \text { done using the SPSS version 23.0 for Windows. The results of the study show that the } \\ \text { experience of project activities has a significant effect on the scientific literacy skills in } \\ \text { three competencies. These competencies are to explain scientific phenomena, evaluate } \\ \text { Keywords } \\ \text { Literacy skills } \\ \text { and design scientific investigations and interpret scientific evidence and data. } \\ \text { Competence in evaluating and designing scientific investigations has the greatest } \\ \text { Project activities }\end{array}$

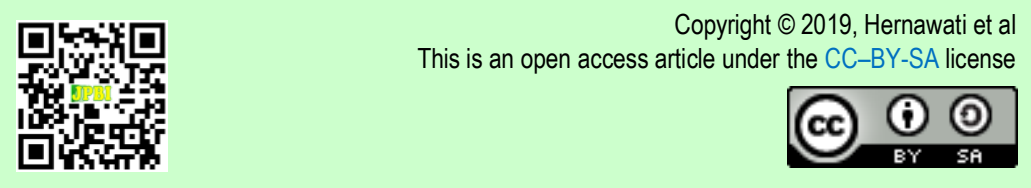

How to cite: Hernawati, D., Amin, M., Al Muhdhar, M. H. I., \& Indriwati, S. E. (2019). Science literacy skills through the experience of project activities with assisted local potential based learning materials. JPBI (Jurnal Pendidikan Biologi Indonesia), 5(1), 159-168. doi: https://doi.org/10.22219/jpbi.v5i1.7372

\section{INTRODUCTION}

A number of 21 st-Century skills were introduced with various labels and packaged in a number of clusters, i.e. ways of thinking, ways of working, working and life skill in the world (Binkley et al., 2014; Tan, Choo, Kang,

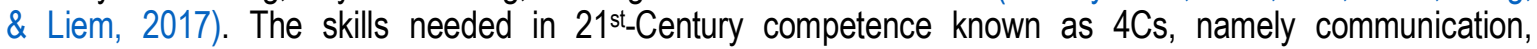
collaboration, critical thinking, and creativity (Chu, Reynolds, Tavares, Notari, \& Lee, 2017; Heinrichs, 2016; Osman, Hamid, \& Hassan, 2009; Skills, 2009; Talat \& Chaudhry, 2014; Wilborn, 2013). In general, mastery of 21 st-century skills can be focused on creating high-quality human resources with higher order thinking skills (Bell, 2010; Talat \& Chaudhry, 2014; Tindangen, 2018). Today the implementation of science education 
systems has recommended ways to understand students from complex systems (Chu et al., 2017; Ghaffarzadegan, Larson, \& Hawley, 2017; Spraragen et al., 2014; Uswatun \& Widiyanto, 2018; Young, 2013). An example in the structure-function framework that has been used to support and examine student systems thinking (Dauer \& Dauer, 2016; Speth et al., 2014; Vattam et al., 2011). Known system thinking includes general systems thinking (systems thinking that shows the relationship between structure and function) and dynamic systems thinking (Arnold \& Wade, 2015; Carey et al., 2015; Grohs, Krik, Soledad, \& Knight, 2018; Monat \& Gannon, 2018, 2015).

Scientific literacy skills have been seen as the competencies needed to improve the ability to think dynamically about science in relation to personal, social, political, economic, and other issues. Holbrook and Rannikmae (2009) suggested that scientific literacy skills can be developed through science education. Science education related to the ability to use scientific knowledge and skills creatively based on sufficient evidence with daily life in solving real problems based on reasoning that can be understood based on scientific phenomena (Campbell, Zhang, \& Neilson, 2011; Dragoş \& Mih, 2015; Gormally, Brickman, \& Lutz, 2012; Gultepe, 2016; Holbrook \& Rannikmae, 2009; Karamustafaoğlu, 2011; Trna, Trnova, \& Sibor, 2012; Turiman, Omar, Daud, \& Osman, 2012). Science is not just an accumulation of visible evidence, but observations that require interpretation and inference, so the lack of association of findings is explicit with science content (Campbell et al., 2011). However, the Program International Student Assessment (PISA) reported that the average score of achievement of science literacy in Indonesia was still low. Indonesia ranked, in 2012, is 64th from 65 participating countries (OECD, 2013). The similar finding also found in students' literacy related to health issue (Permana, Suwono, \& Listyorini, 2016).

Students' science literacy can be promoted in their learning process (Dragoş \& Mih, 2015; Gormally, Brickman, Hallar, \& Armstrong, 2009; Turiman et al., 2012). Learning process in the view of constructivism is creating an activity that allows students to build their own knowledge (Schunk, 2012). Referring to the philosophy of constructivism, the learning outcome can be achieved through a learning process that prioritizes the development of creativity, activities, and needs of students (Tantrarungroj \& Suwannatthachote, 2012). The achievement of learning outcomes can be designed by providing learning experiences that involve mental and physical processes through various interactions. Provision of project assignments as one of the activities that can link academic content with real contexts arouses student enthusiasm for problem-solving and decision making (Baş, 2011; Bell, 2010; Johnson, 2009; See, Rashid, \& Bakar, 2015; Sookpatdhe \& Soranastaporn, 2016). The success of the project in learning depends on the number of student activities and a good learning environment (Habók \& Nagy, 2016). By utilizing students' real-life condition, they can promote their ability related to science literacy. The students can accommodate their ability to identify questions, gain new knowledge, explain scientific phenomena, and draw conclusions based on facts (Dragoş \& Mih, 2015; Holubova, 2008; Schwartz, Tessman, \& Mcdonald, 2013; Sookpatdhe \& Soranastaporn, 2016).

Furthermore, Baxter (2007) suggest that effective learning is not just a good teaching outcome, but the use of local resources that have a direct contribution as learning resources in order to develop the potential of students. The diversity of animals and plants that are characteristic of the Tasikmalaya region is a challenge to be used as a learning resource. It remains a major challenge to utilize biology learning resources by maximizing local potential as a solution to reduce the effects of boredom and develop local resources (Prabowo, Nurmiyati, \& Maridi, 2016). In this case, the students will carry out learning experiences by utilizing local potential based learning. For this reason, this study aims to explain the students' science literacy skills through project experience with the help of local potential-based teaching materials.

\section{METHOD}

This research was aimed to explain students' science literacy skills through project experience with the help of local potential-based teaching materials. The local potential used was animals and plants which became characteristic of the Tasikmalaya region. The activity carried out by students was to explore animals and plants related to their taxonomy and genetic relationship. The research design used was quasi-experimental, pre-and posttest control group design (Creswell \& Guetterman, 2019). The research subjects were students of biology education at the undergraduate level. The population used was 180 people spread in 5 classes. Sampling was done by using purposive sampling technique. The equivalence of the study sample was carried out by placement test. The sample used was one class for the class given treatment with a total of 35 students, while the control class was used as a comparison only. The study was conducted for one semester with a research period of 6 months.

The instruments of scientific literacy skills used are in the form of test techniques that are given before and after the treatment. The items of the questions are arranged based on competence to explain scientific phenomena (variable 1), evaluate and design scientific investigations (variable 2), interpret scientific evidence 
and data (variable 3) adapted from PISA (2015) and Graber (Holbrook \& Rannikmae, 2009). The question items used have been validated by experts and have been tested (instrument trial). The analysis used in calculating the validity of each question is Anates software version 4.0.9 for Windows. The technique used to analyze the data was inferential statistical analysis with ANCOVA analysis at a significant level of $5 \%$ (Mertler \& Reinhart, 2016). Firstly, the prerequisites of the analysis of the data obtained were tested including normality test (Kolmogorov-Smirnov) and variance homogeneity (Levene's-Test) (O'Neill \& Mathews, 2000). The prerequisite test results for each competency are $0.128 ; 0.30 ; 0.444$. All data testing was done by using the SPSS version 23.0 for Windows.

\section{RESULTS AND DISCUSSION}

The results of the scientific literacy skills analysis for each competency are explained in Table 1; Table 2; and Table 3. The results of the covariate analysis in Table 1 can be explained that there is an influence on the experience of project activities on the scientific literacy of competency skills explaining scientific phenomena by removing the pre-test as a covariate at a significance of 0.006 with a value far from 0.05 . Simultaneously there is a significant influence on the experience of project activities to explain scientific phenomena (variable 1) at a significance of 0.005 with an $F$ value of 5.839 . While the significance of competency variables explaining scientific phenomena is 0.001 with Sig. $<0.05$ and $F$ values of 11.198.

Table 1. Summary of test results for ANCOVA competencies explaining scientific phenomena

\begin{tabular}{lrrrrr}
\hline \multicolumn{1}{c}{ Source } & Type III Sum of Squares & df & Mean Square & \multicolumn{1}{c}{ F } & Sig. \\
\hline Corrected Model & $42.071 \mathrm{a}$ & 2 & 21.036 & 5.839 & .005 \\
Intercept & 282.250 & 1 & 282.250 & 78.347 & .000 \\
Group & 4.349 & 1 & 4.349 & 1.207 & .006 \\
pretest_variabe1 & 40.343 & 1 & 40.343 & 11.198 & .001 \\
Error & 241.372 & 67 & 3.603 & & \\
Total & 4043.000 & 70 & & & \\
Corrected Total & 283.443 & 69 & & & \\
\hline
\end{tabular}

Table 2 explains the significance values of the corrected model with the conclusion that there is a significant influence on the experience of project activities on the competence of scientific literacy skills to evaluate and design scientific investigations at a significance of 0.000 with an $F$ value of 13.839 . While the significance for the competence variable evaluating and designing scientific investigations is 0.026 with Sig. $<0.05$ and $F$ values of 5.183. The experience of project activities has a significant effect on the competency of scientific literacy skills evaluating and designing scientific investigations (variable 2) with pre-test as a covariate at a 0.05 significance level.

Table 2. Summary of test results ANCOVA evaluates and designs scientific investigations

\begin{tabular}{lrrrrr}
\hline \multicolumn{1}{c}{ Source } & Type III Sum of Squares & df & Mean Square & \multicolumn{1}{c}{ F } & Sig. \\
\hline Corrected Model & $69.765^{\mathrm{a}}$ & 2 & 34.883 & 13.839 & .000 \\
Intercept & 456.786 & 1 & 456.786 & 181.224 & .000 \\
Group & 55.312 & 1 & 55.312 & 21.944 & .000 \\
Pretest_variabe2 & 13.065 & 1 & 13.065 & 5.183 & .026 \\
Error & 168.878 & 67 & 2.521 & & \\
Total & 1939.000 & 70 & & & \\
Corrected Total & 238.643 & 69 & & & \\
\hline
\end{tabular}

Table 3 significance values in the corrected model can be concluded that there is a significant influence on the experience of project activities on the scientific literacy skills competencies interpreting the evidence and scientific data at a significance of 0.003 with an $\mathrm{F}$ value of 6.518 . While the significance for the competency variable interprets the evidence and scientific data is 0.001 with Sig. $<0.05$ and $F$ values of 12.4476 . Experience of project activities on the scientific literacy skills of competence interpreting scientific evidence and data (variable 3 ) with a pre-test as a covariate at a significance level of 0.05 . The significance value obtained is 0.045 .

The results of the statistical analysis are inferentially concluded that the experience of project activities has a significant effect on the scientific literacy skills in three competencies. Competence in evaluating and designing scientific investigations has the greatest significance compared to the other two competencies at the significance of 0.000 with an $F$ value of 13.839 as explained in Figure 1. These results reinforce that project 
activity assisted by local potential based teaching materials have a profound effect on scientific literacy skills of the students. Project activity activities carried out during the learning process using the stages or syntax of Hung, Keppell, and Jong (2004) are factually preceded by the student orientation stage on the problem. This stage is the initial activity of the learning process starting with information on the achievement of course learning, information on real phenomena as a source of problems and providing motivation in connection with making projects (Lewinsohn et al., 2014; Macklin, 2001).

Table 3. Summary of ANCOVA test results interprets scientific evidence and data

\begin{tabular}{lrrrrr}
\hline \multicolumn{1}{c}{ Source } & Type III Sum of Squares & df & Mean Square & \multicolumn{1}{c}{ F } & \multicolumn{1}{c}{ Sig. } \\
\hline Corrected Model & $40.211^{\mathrm{a}}$ & 2 & 20.105 & 6.518 & .003 \\
Intercept & 205.759 & 1 & 205.759 & 66.708 & .000 \\
Group & 12.927 & 1 & 12.927 & 4.191 & .045 \\
Pretest_variabe3 & 38.482 & 1 & 38.482 & 12.476 & .001 \\
Error & 206.661 & 67 & 3.084 & & \\
Total & 2027.000 & 70 & & & \\
Corrected Total & 246.871 & 69 & & & \\
\hline
\end{tabular}

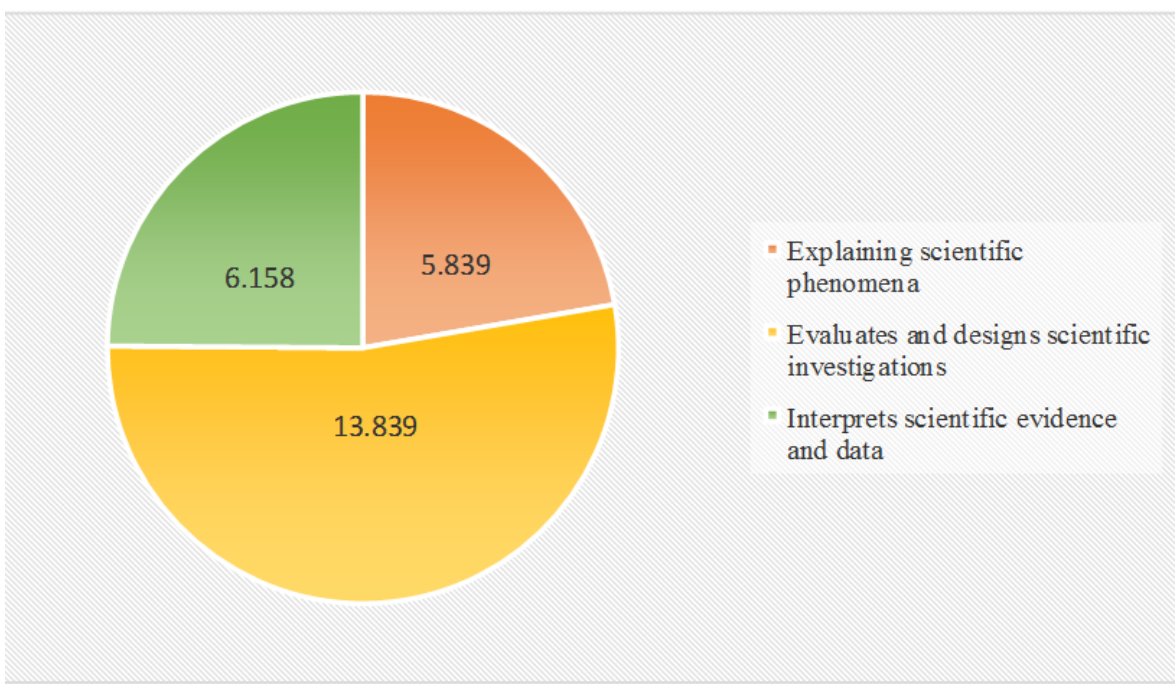

Figure 1. Results of a comparison of the three competencies of scientific literacy skills

The second stage of project activities is organizing students to study. This stage of the activity is how students can prepare through group formation, stabilizing problems and tracing sources. According to Cook and Walsh (2012), these activities help students to foster reinforcement in scientific literacy skills. Strengthening concept was done through critical analytical assignments, which directly train the ability of prospective teacher students in 1) Identifying assumptions, evidence, and reasoning in related texts; 2) Evaluating scientific arguments and evidence from different sources (e.g. newspapers, internet, and research article). This activity is carried out to obtain valid facts and information with the help of all forms of learning resources optimally. Through this activity, students can directly present important information that will be utilized. In addition, students can raise important questions raised in the entire article analyzed (Cook \& Walsh, 2012; Holbrook \& Rannikmae, 2009; Macklin, 2001; Speros, 2005).

The third stage of project activities is guiding students to carry out project activities. Many activities carried out by students in this stage, begin the learning process by observing objects in accordance with the animal and plant characteristic. Students identifying questions and distinguishing it, then they answered it scientifically. Examples of when students are faced with a number of fish specimens, character observations are made about the state of the head (head shape, head size, mouth, jaw, eyes, nostril, operculum), body condition (body shape, body symmetry, scales, lateral lines), the state of the tail (shape / type, tail) and other characters that can be used for identification. Based on the results above, several problem formulations have been collected which require answers.

The examples of results of answers to prospective teacher students when writing the problem statement:

1) Are there differences in the body shape between freshwater fish and seawater fish?

2) How to do fish body measurements? 
3) Are there differences in fin fingers in fish?

4) Are there different scales between freshwater fish and seawater fish?

In connection with this activity, students learn how to explore questions scientifically and evaluate them. Exploration carried out in the context of collecting data based on experimental results. Some research showed that these activities help students to improve their science literacy skills (Anelli, 2011; Dragoş \& Mih, 2015; Holbrook \& Rannikmae, 2009).

Other circumstances when students are faced with a number of specimens from the frog group, character observations are carried out about 1 ) the dorsal part of the head (caput), oral cavity and snout; 2) fingers and toes; 3) other characters (supra tympanum folds, dorsolateral folds, coarse or fine-grain skin, body color). Students organize data to make hypotheses, analyze data according to investigative studies and conduct analysis/discussion analysis. The ability to obtain information/data is obtained quantitatively and qualitatively as a basis for testing hypotheses.

The examples of results of student answers when making hypotheses:

1) There is a difference in the swimming membrane on the fingers of a frog

2) There is a difference in the swimming membrane on the toes of frog

3) There are body color differences in frogs

4) There are differences in the skin on frogs

In this connection, students learn how to analyze and interpret data and present it in the form of hypotheses. These activities are activities that train the scientific literacy skills of students.

The fourth stage of project activities is the development and presentation of project results. The stages of the activities carried out are collaborating in the preparation and presentation of reports as a result of the investigation. The form of presentation is in the form of a lab report as study material for discussion presentations. Examples of student results when generalizing and conclusions:

"The shape of the body of the fish is almost like that of a carp, but it is slimmer with a thin snout and in the corner of its mouth there is one pair of touching grunts. The movements are more agile than carp. The body color is silvery white, the back is dark, the front edge of the dorsal fin and the outer edge of the caudal fin is black. The dorsal fin is supported by 3 hard fingers and 8 soft fingers. The anal fin is supported by 3 hard fingers and 5 soft fingers. The pelvic fin is supported by 2 hard fingers and 8 soft fingers. The pectoral fin is supported by 1 hard radius and 15-16 soft fingers. The number of lateral lines is $28-29$ pieces."

The conclusions obtained are reinforced by relevant reference libraries so that products as a result of project work can be made in the form of posters. In connection with the above, students learn a lot at this stage, including how to make and justify proper predictions, transform data from one representation to another, distinguish between arguments based on scientific evidence and theories based on other considerations, evaluate scientific arguments and evidence from different sources, and draw the right conclusions.

The fifth stage of project activities is analyzing and evaluating the process of project activities. The final stage of this activity is that students reflect on the processes taken during the project activities. Reflection is a way of thinking about what has been learned or already done. Reflection is a response to new events, activities or knowledge received. Students learn how to explain and evaluate various ways to ensure data reliability, data objectivity, and general explanatory abilities and explain the potential implications of scientific knowledge for the wider community. This reflection can be in the form of student notes, impressions and suggestions, direct questions, discussions, and works. The key to all this is how that knowledge settles in the minds of students. One of the examples of the problem of scientific literacy skills that refers to the competence of evaluating and designing scientific investigations are:

Natural disturbances or threats that can interfere with the life of a turtle at any time, including:

- Predation of hatchlings, both for hatchlings that have just come out of the nest (including by wild boar, wild dogs, monitor lizards, and eagles) as well as on hatchlings in the sea (including by cucut fish).

- Disease, which is caused by bacteria, viruses, or because of pollution of the aquatic environment.

- Climate change causes sea levels to rise and a lot of beach laying erosion occurs so that it affects the change in hatchability and balance of hatchling sex ratio

Question: Based on this, what efforts can be made to maintain hatchlings in cultivation? 
The philosophical aspects of higher education as a place to prepare students to be able to live in the community, the learning experience involving student project activities is enabling and very important learning to be developed. Viewed from the context of improving the quality of education, this learning process is one of the lessons that can be used to improve the learning system that involves changes in pedagogy.

One of the principles of science learning is an active process. This is the main point in scientific literacy skills. This principle implies that science learning must involve activities carried out by students, not by lecturers. Students must be given physical or sensory motoric experience as a basis for developing abstract ideas. Students have control over what they want to learn. This is in line with some research revealed that learning can be enjoyed when they are given more responsibility (Cook-Sather, 2010; Swain, 2012; Yap, Neo, $\& \mathrm{Neo}, 2016)$. This opportunity makes it easy for lecturers to use various opportunities for learning by doing. The active process has mental and physical implications. Hands-on activities are not enough; students must have minds-on practices. The implementation of project-based learning was giving meaningful experience to the student (Schwartz et al., 2013) because they will force their creativity to solve problems (Chiang \& Lee, 2016; Isabekov \& Sadyrova, 2018)

Learning is basically a meaningful process to achieve competence or life skills. The meaning of life occurs in context. Therefore learning will be meaningful if the learning material is associated with the real life of students (Holubova, 2008; Schwartz et al., 2013). The principle is in line with the results of the study of See et al. (2015) and Skills (2009) which show that if the lecturer creates meaningful learning activities on resources, the strategy and context are in accordance with student life, then the level of cooperation, communication, critical skills, and academic abilities will increase. This is confirmed by a statement from (Zubaidah, 2016) that knowledge grows and expands exponentially so that indicators of success are based on complex abilities.

Findings from cognitive psychology provide a basic theory for improving learning in general. The basic premise in cognitive psychology is that learning is a process of constructing new knowledge based on existing knowledge. The concept from David Ausubel of emphasizing meaningful learning processes hints at the importance of repetition before learning begins (Ausubel, 1968). This kind of mental activity helps students reformulate new information or restructure their knowledge into a broader/more complete cognitive structure so that it reaches a deep understanding. Scientific phenomena that can be accessed directly and observed are mental processes that can be done to obtain facts through various abilities (Speros, 2005). One example, after obtaining observational data in a laboratory, students can carry out inference activities through explanations and conclusions. Scientific literacy skills can be produced not only through competency to explain phenomena scientifically, but also require scientific evidence (Gormally et al., 2009, 2012). Therefore, any scientific statement must be in harmony with empirical evidence and new evidence can revise pre-existing scientific knowledge. But it cannot be denied that it is very difficult to make observations and interpretations that are truly objective (Lederman, 2007).

The findings of this study have implications that the achievement of scientific literacy skills refers to the science process, namely the mental processes involved when answering a question or solving a problem (Gormally et al., 2012). The inclusiveness of scientific literacy as a major competency for learning science tends to develop on scientific questions. The hope is as Amin (2017) said that the achievement of scientific literacy products is to be human beings who are able to keep up with the times, this can have the provision in facing increasingly complex life problems. In line with the view of Hudha, A. M., Amin, M., and Bambang (2016) who argued that the century of knowledge needed high-quality human resources. The implication of the result is a teacher be able to construct students' scientific literacy skills through experience in project activities. It is very possible for local potential based teaching materials to be used at the learning process by the teacher at the secondary school level to supporting the improvement of the learning achievement with relevant material.

\section{CONCLUSION}

The result showed that the variable of explaining scientific phenomena at a significance of 0.005 with an $F$ value of 5.839; evaluating and designing scientific investigations at a significance of 0.000 with an $F$ value of 13.839 and interpreting scientific evidence and data at a significance of 0.003 with an $F$ value of 6.518 . The experience of project activities has a significant effect on the scientific literacy skills in three competencies. This result is as an implication in the learning process to be able to construct scientific literacy skills through experience in project activities. It is very possible for local potential based teaching materials to be used at the learning process by the teacher at the secondary school level to supporting the improvement of the learning achievement with relevant material. 


\section{REFERENCES}

Amin, M. (2017). Sadar berprofesi guru sains, sadar literasi: Tantangan guru di abad 21. In A. Rahardjanto (Ed.), Biologi, Pembelajaran, dan Lingkungan Hidup Perspektif Interdisipliner (pp. 9-20). Malang, Indonesia: Prodi Pendidikan Biologi-FKIP bekerjasama dengan Pusat Studi Lingkungan dan Kependudukan (PSLK) Universitas Muhammadiyah Malang. Retrieved from http://research-report.umm. ac.id/index.php/research-report/article/view/967/1337

Anelli, C. (2011). Scientific literacy: What is it, are we teaching it, and does it matter? American Entomologist, 57(4), 235-243. Retrieved from http://entomology.wsu.edu/wp-content/uploads/2012/02/Anelli2011scien tific-lit.pdf

Arnold, R. D., \& Wade, J. P. (2015). A definition of systems thinking: A systems approach. In Procedia Computer Science (Vol. 44, pp. 669-678). Elsevier Masson SAS. doi: https://doi.org/10.1016/j.procs. 2015.03.050

Ausubel, D. P. (1968). Educational psychology: A cognitive view. New York, US: Holt Rinehart and Winston. Retrieved from https://psycnet.apa.org/record/1968-35017-000

Baş, G. (2011). Investigating the effects of project-based learning on students' academic achievement and attitudes towards English lesson. TOJNED: The Online Journal Of New Horizons In Education, 1(4), 115. Retrieved from https://www.tojned.net/journals/tojned/articles/v01i04/v01i04-01.pdf

Baxter, D. (2007). Teaching strategies for adult learners. Rivier Academic Journal, 3(2), 1-3. Retrieved from https://www2.rivier.edu/journal/ROAJ-Fall-2007/J120a-Celebrating-PedagogyX-Baxter.pdf

Bell, S. (2010). Project-based learning for the 21st century: Skills for the future. The Clearing House: A Journal of Educational Strategies, Issues and Ideas, 83(2), 39-43. doi: https://doi.org/10.1080/0009865 0903505415

Binkley, M., Erstad, O., Herman, J., Raizen, S., Ripley, M., Miller-Ricci, M., \& Rumble, M. (2014). Defining twenty-first century skills. In Assessment and teaching of 21st century skills. doi: https://doi.org/10.1007 1978-94-007-2324-5_2

Campbell, T., Zhang, D., \& Neilson, D. (2011). Model based inquiry in the high school physics classroom: An exploratory study of implementation and outcomes. Journal of Science Education and Technology, 20(3), 258-269. doi: https://doi.org/10.1007/s10956-010-9251-6

Carey, G., Malbon, E., Carey, N., Joyce, A., Crammond, B., \& Carey, A. (2015). Systems science and systems thinking for public health: A systematic review of the field. BMJ Open, 5(12), 1-9. doi: https:// doi.org/10.1136/bmjopen-2015-009002

Chiang, C. L., \& Lee, H. (2016). The effect of project-based learning on learning motivation and problemsolving ability of vocational high school students. International Journal of Information and Education Technology, 6(9), 709-712. doi: https://doi.org/10.7763/IJIET.2016.V6.779

Chu, S. K. W., Reynolds, R. B., Tavares, N. J., Notari, M., \& Lee, C. W. Y. (2017). 21st Century skills development through inquiry-based learning. Switzerland: Springer. doi: https://doi.org/10.1007/978981-10-2481-8

Cook-Sather, A. (2010). Students as learners and teachers: Taking responsibility, transforming education, and redefining accountability. Curriculum Inquiry, 40(4), 555-575. Retrieved from http://repository.brynmawr. edu/edu_pubs

Cook, P., \& Walsh, M. (2012). Collaboration and problem-based learning: Integrating information literacy into a political science. Communications in Information Literacy, 6(1), 59-72. Retrieved from http://www.com minfolit.org/index. php?journal=cil\&page=article\&op=view\&path\%5B\%5D=v6i1p59

Creswell, J. W., \& Guetterman, T. C. (2019). Educational research: Planning, conducting, and evaluating quantitative and qualitative research (6th Ed.). New York, US: Pearson. Retrieved from https://www.pearson.com/us/higher-education/program/Creswell-Educational-Research-Planning-Cond ucting-and-Evaluating-Quantitative-and-Qualitative-Research-plus-My-Lab-Education-with-EnhancedPearson-e-Text-Access-Card-Package-6th-Edition/PGM335066.html

Dauer, J., \& Dauer, J. (2016). A framework for understanding the characteristics of complexity in biology. International Journal of STEM Education, 3, 13. doi: https://doi.org/10.1186/s40594-016-0047-y

Dragoș, V., \& Mih, V. (2015). Scientific literacy in school. Procedia-Social and Behavioral Sciences, 209, $167-$ 172. doi: https://doi.org/10.1016/j.sbspro.2015.11.273

Ghaffarzadegan, N., Larson, R., \& Hawley, J. (2017). Education as a complex system. Systems Research and Behavioral Science, 34(3), 211-215. doi: https://doi.org/10.1002/sres.2405 
Gormally, C., Brickman, P., Hallar, B., \& Armstrong, N. (2009). Effects of inquiry-based learning on students' science literacy skills and confidence. International Journal for the Scholarship of Teaching and Learning, 3(2), 1-22. doi: https://doi.org/10.20429/ijsotl.2009.030216

Gormally, C., Brickman, P., \& Lutz, M. (2012). Developing a test of scientific literacy skills (TOSLS): Measuring undergraduates' evaluation of scientific information and arguments. CBE Life Sciences Education, 11(4), 364-377. doi: https://doi.org/10.1187/cbe.12-03-0026

Grohs, J. R., Krik, G. R., Soledad, M. M., \& Knight, D. B. (2018). Assessing systems thinking: A tool to measure complex reasoning through ill-structured problems. Thinking Skills and Creativity, 28, 110130. doi: https://doi.org/10.1016/j.tsc.2018.03.003

Gultepe, N. (2016). High school science teachers' views on science process skills. International Journal of Environmental \& Science Education, 11(5), 779-800. doi: https://doi.org/10.12973/ijese.2016.348a

Habók, A., \& Nagy, J. (2016). In-service teachers' perceptions of project-based learning. SpringerPlus, 5, 83. doi: https://doi.org/10.1186/s40064-016-1725-4

Heinrichs, C. R. (2016). Exploring the influence of 21st century skills in a dual language program: A case study. International Journal of Teacher Leadership, 7(1), 37-56. Retrieved from https://files.eric.ed.gov/ fulltext/EJ1137667.pdf

Holbrook, J., \& Rannikmae, M. (2009). The meaning of scientific literacy. International Journal of Environmental and Science Education, 4(3), 275-288. doi: https://doi.org/10.1080/09500690601007549

Holubova, R. (2008). Effective teaching methods - Project-based learning in physics. US-China Education Review, 5(12), 27-36. Retrieved from https://files.eric.ed.gov/fulltext/ED504949.pdf

Hudha, A. M., Amin, M., \& Bambang, S. (2016). Study of instructional models and syntax as an effort for developing 'OIDDE' instructional model. JPBI (Jurnal Pendidikan Biologi Indonesia), 2(2), 109-124. doi: https://doi.org/10.22219/jpbi.v2i2.3448

Hung, V. H. K., Keppell, M., \& Jong, M. S. Y. (2004). Learners as producers : Using project based learning to enhance meaningful learning through digital video production. In Proceedings of the 21st ASCILITE Conference. doi: https://doi.org/10.1002/cctc.201601670

Isabekov, A., \& Sadyrova, G. (2018). Project-based learning to develop creative abilities in students. In J. Drummer, G. Hakimov, M. Joldoshov, T. Köhler, \& S. Udartseva (Eds.), Vocational Teacher Education in Central Asia. Technical and Vocational Education and Training: Issues, Concerns and Prospects (pp. 43-49). Springer, Cham. doi: https://doi.org/10.1007/978-3-319-73093-6_4

Johnson, N. F. (2009). Simply complexity: A clear guide to complexity theory. Oxford: Oneworld. Retrieved from https://philpapers.org/rec/JOHSCA-4

Karamustafaoğlu, S. (2011). Improving the science process skills ability of science student teachers using I diagrams. Eurasian Journal of Physics and Chemistry Education, 3(1), 26-38. Retrieved from www. acarindex.com/dosyalar/makale/acarindex-1423880494.pdf

Lederman, N. G. (2007). Nature of science: Past, present, and future. In S. K. Abell \& N. G. Lederman (Eds.), Handbook of research in science education (pp. 831-879). Mahwah, New Jersey: Lawrence Erlbaum Publishers. Retrieved from https://serc.carleton.edu/resources/40717.html

Lewinsohn, T. M., Attayde, J. L., Fonseca, C. R., Ganade, G., Jorge, L. R., Kollmann, J., ... Weisser, W. W. (2014). Ecological literacy and beyond: Problem-based learning for future professionals. AMBIO, 44(2), 154-162. doi: https://doi.org/10.1007/s13280-014-0539-2

Macklin, A. S. (2001). Integrating information literacy using problem-based learning. Reference Services Review, 29(4), 306-313. doi: https://doi.org/10.1108/EUM0000000006493

Mertler, C., \& Reinhart, R. V. (2016). Advanced and multivariate statistical methods: Practical application and interpretation: Sixth edition. Taylor and Francis. doi: https://doi.org/10.4324/9781315266978

Monat, J. P., \& Gannon, T. (2018). Applying systems thinking to engineering and design. Systems, 6(3), 34. doi: https://doi.org/10.3390/systems6030034

Monat, J. P., \& Gannon, T. F. (2015). What is systems thinking? A review of selected literature plus recommendations. American Journal of Systems Science, 4(1), 11-26. doi: https://doi.org/10.5923/j. ajss.20150401.02

O'Neill, M. E., \& Mathews, K. (2000). A weighted least squares approach to Levene's test of homogeneity of variance. Australian and New Zealand Journal of Statistics, 42(1), 81-100. doi: https://doi.org/10.1111/ 1467-842X.00109

OECD. (2013). Survey international programme for international student assessment (PISA). Retrieved from http://www.oecd.org/pisal 
Osman, K., Hamid, S. H. A., \& Hassan, A. (2009). Standard setting: Inserting domain of the 21st century thinking skills into the existing science curriculum in Malaysia. Procedia - Social and Behavioral Sciences, 1(1), 2573-2577. doi: https://doi.org/10.1016/j.sbspro.2009.01.454

Permana, T. I., Suwono, H., \& Listyorini, D. (2016). Preliminary study of health literacy in high school student in Malang. In A. Rahardjanto (Ed.), Biologi, Pembelajaran, dan Lingkungan Hidup Perspektif Interdisipliner (pp. 430-434). Malang: Prodi Pendidikan Biologi-FKIP bekerjasama dengan Pusat Studi Lingkungan dan Kependudukan (PSLK) Universitas Muhammadiyah Malang. Retrieved from https://www.researchgate.net/publication/321824238_Preliminary_Study_Of_Health_Literacy_In_High_ School_Student_In_Malang

PISA. (2015). Draft science framework. Retrieved from https://www.oecd.org/pisa/pisaproducts/Draft PISA 2015 Science Framework .pdf

Prabowo, D. L., Nurmiyati, \& Maridi. (2016). Pengembangan modul berbasis potensi lokal pada materi ekosistem sebagai bahan ajar di SMA N 1 Tanjungsari, Gunungkidul. In Proceeding Biology Education Conference (Vol. 13, pp. 192-195). Surakarta: Pendidikan Biologi FKIP UNS. Retrieved from https://jurnal.uns.ac.id/prosbi/article/view/5692

Schunk, D. H. (2012). Learning theories: An educational perspective (6th ed.). Boston: Allyn \& Bacon. doi: https://doi.org/10.1017/CBO9781107415324.004

Schwartz, K., Tessman, D., \& Mcdonald, D. (2013). The value of relevant, project-based learning to youth development (Vol. 8). Retrieved from https://jyd.pitt.edu/ojs/jyd/article/viewFile/109/95

See, Y. G., Rashid, A. M., \& Bakar, A. R. (2015). The effect of project based learning on level of content knowledge of pre-vocational subject. Mediterranean Journal of Social Sciences, 6(6), 369-375. doi: https://doi.org/10.5901/mjss.2015.v6n6s4p369

Skills, T. P. for 21st C. (2009). Framework for 21st century learning. P21 Framework Definitions. The Partnership for 21st Century Skill. Retrieved from https://files.eric.ed.gov/fulltext/ED519462.pdf

Sookpatdhe, T., \& Soranastaporn, S. (2016). Simulation and project based learning for developing creativity: From classroom to real life. ThaiSim Journal: Learning Development (TSJLD), 1(1), 85-105. Retrieved from http://www.thaisim.org/sgld/

Speros, C. (2005). Health literacy: concept analysis. Journal of Advanced Nursing, 50(6), 633-640. doi: https://doi.org/10.1111/j.1365-2648.2005.03448.x

Speth, E. B., Shaw, N., Momsen, J., Reinagel, A., Le, P., Taqieddin, R., \& Long, T. (2014). Introductory biology students' conceptual models and explanations of the origin of variation. CBE-Life Sciences Education, 13(3), 529-539. doi: https://doi.org/10.1187/cbe.14-02-0020

Spraragen, M., Hanneman, L., Madni, A. M., Richey, M., Hubbard, W., \& Nance, M. (2014). A complex sociotechnical systems approach to provisioning educational policies for future workforce. In Procedia Computer Science (Vol. 28, pp. 857-864). Elsevier Masson SAS. doi: https://doi.org/10.1016/j.procs. 2014.03.102

Swain, M. S. (2012). Perceived responsibility for learning in college students: A construct validity study. James Madison University. Retrieved from https://commons.lib.jmu.edu/master201019

Talat, A., \& Chaudhry, H. F. (2014). The effect of PBL and 21st century skills on students' creativity and competitiveness in private schools. The Lahore Journal of Business, 2(2), 89-114. Retrieved from http://www.lahoreschoolofeconomics.edu.pk/businessjournals/V2issue2/05TalatandChaudhry FINAL.pdf

Tan, J. P. L., Choo, S. S., Kang, T., \& Liem, G. A. D. (2017). Educating for twenty-first century competencies and future-ready learners: research perspectives from Singapore. Asia Pacific Journal of Education, 37(4), 425-436. doi: https://doi.org/10.1080/02188791.2017.1405475

Tantrarungroj, P., \& Suwannatthachote, P. (2012). Enhancing pre-service teacher's self-efficacy and technological pedagogical content knowledge in designing digital media with self-regulated learning instructional support in online project-based learning. Creative Education, 3(8B), 77-81. doi: https://doi. org/10.4236/ce.2012.38b017

Tindangen, M. (2018). Inquiry-based learning model to improve higher order thinking skills. Asian Social Science, 14(7), 39-46. doi: https://doi.org/10.5539/ass.v14n7p39

Trna, J., Trnova, E., \& Sibor, J. (2012). Implementation of inquiry-based science education in science teacher training. Journal of Educational and Instructional Studies, 2(4), 199-209. Retrieved from http://www. wjeis.org/FileUpload/ds217232/File/23.trna.pdf

Turiman, P., Omar, J., Daud, A. M., \& Osman, K. (2012). Fostering the 21st century skills through scientific literacy and science process skills. Procedia - Social and Behavioral Sciences, 59, 110-116. doi: https:/l 
doi.org/10.1016/j.sbspro.2012.09.253

Uswatun, D. A., \& Widiyanto, R. (2018). Analisis aktivitas peserta didik dalam pembelajaran berbasis scientific approach di sekolah dasar sebagai implementasi 21st century skills. JIPVA (Jurnal Pendidikan IPA Veteran), 2(2), 174-188. doi: https://doi.org/10.31331/jipva.v2i2.680

Vattam, S. S., Goel, A. K., Rugaber, S., Hmelo-Silver, C. E., Jordan, R., Steven, G., \& Sinha, S. (2011). Understanding complex natural systems by articulating structure-behavior-function models. Educational Technology and Society, 14(1), 66-81. Retrieved from https://www.academia.edu/32828789/Under standing_Complex_Natural_Systems_by_Articulating_Structure-Behavior-Function_Models

Wilborn, J. W. (2013). Teacher self-efficacy: Common core state standards within a 21st century skills framework. Doctoral Dissertations and Projects. Liberty University. Retrieved from https://digital commons.liberty.edu/doctoral/650

Yap, W. L., Neo, M., \& Neo, T. K. (2016). The impact of the role of teacher and balance of power in transforming conventional teaching to learner-centered teaching in Malaysian institution of higher education. Pertanika Journal of Social Sciences and Humanities, 24(4), 1849-1868. Retrieved from http://eprints. intimal.edu.my/710/1/Theimpactoftheroleofteacherandbalanceofpowerintransformingconve ntionalteachingtolearner-centeredteachinginMalaysianinstitutionofhighereducation.pdf

Young, M. (2013). Curriculum theory: What it is and why it is important. In Proceeding of the first meeting of the European Association of Curriculum Studies (pp. 191-201). Braga: University of Minho. doi: https:// doi.org/10.1590/198053142851

Zubaidah, S. (2016). Keterampilan abad ke-21: Keterampilan yang diajarkan melalui pembelajaran. In Seminar Nasional Pendidikan dengan tema "Isu-Isu Strategis Pembelajaran MIPA Abad 21" (pp. 1-17). Sintang-Kalimantan Barat: Program Studi Pendidikan Biologi STKIP Persada Khatulistiwa. Retrieved from https://www.researchgate.net/publication/318013627_KETERAMPILAN_ABAD_KE-21_KETERAM PILAN_YANG_DIAJARKAN_MELALUI_PEMBELAJARAN 